ZLOBIN Maksim Aleksandrovich, postgraduate student at the Dobroljubov State Linguistics University of Nizhny Novgorod (31a Minina St, Nizhny Novgorod, Russia, 603155; zlobinmaxim@yandex.ru)

\title{
TECHNIQUES OF THE POLITICAL DISCOURSE FORMATION IN CONDITIONS OF NETWORK SOCIETY
}

\begin{abstract}
The paper considers the main stages and features of the emergence of a network society in Russia, and the connection of this process with the development of telecommunication technologies and the Russian segment of the Internet. The author suggests a brief description of the most typical ways and methods of politicizing content on the Internet, especially with manipulative goals. He emphasizes that communication and discussions on topical issues within network communities and social networks are overwhelmingly politicized, sometimes artificially, contributing to the formation and development of political discourse. Among the main ways of forming political discourse, the impact on the participants of communication on its subject and context can be identified. The author shows the need for a detailed study of the techniques of forming political discourse, including in the interests of national security.
\end{abstract}

Keywords: political discourse, network society, network communication, social network, opposition, Internet, national security

ВАСИЛЕНКО Ирина Алексеевна - доктор политических наук, профессор кафедры российской политики факультета политологии Московского государственного университета им. М.В. Ломоносова (119991, Россия, г. Москва, Ломоносовский пр-кт, 27, корп. 4 «Шуваловский»; vasilenko.irina@таil. ru)

\section{МОСКВА - «УМНЫЙ ГОРОД»: ОСНОВНЫЕ НАПРАВЛЕНИЯ И ПЕРСПЕКТИВЫ СМАРТ-СТРАТЕГИИ РАЗВИТИЯ СТОЛИЦЫ}

Исследование выполнено при финансовой поддержке РФФИ и АНО ЭИСИ в рамках научного проекта № 19-011-31440 ОПН. Статья принята в печать 22.04.2019.

Аннотация. В статье рассматриваются проблемы формирования имиджа Москвы в парадигме «умного города", опирающегося на умное управление, умную среду обитания человека, умные технологии городских коммуникаций. Автор считает, что столица должна уйти от технократического подхода к формированию «умного города» в пользу антропоцентричного - обращенного к человеку, а не к технике. Предлагается разработать «дорожную карту» по развитию «умного города» в столице как гуманистический проект во благо всестороннего развития человека.

Ключевые слова: имидж Москвы, «умный город», смарт-технологии, ребрендинг

$\mathrm{M}$ осква - не только столица России, но и по многим другим критериям уникальный российский город. Сегодня имидж Москвы активно формируется с привлечением смарт-технологий, чтобы сделать столицу лидером среди российских «умных городов».

Важную роль в развитии «умного города» играет Департамент информационных технологий (ДИТ), который осуществил централизацию всех городских систем ИТ в Москве. В столице внедрена электронная система государственных услуг, платформы Интернета вещей (Internet-of-Things), что co3дает надежную базу для реализации новых инициатив в рамках концепции 
«умного города». Инвестиционный потенциал Москвы со значительным отрывом лидирует среди других регионов России: у столицы есть все возможности, чтобы направить значительные экономические ресурсы на развитие «умного города», как это происходит сегодня во всех столичных мегаполисах мира. Ежегодно правительство Москвы инвестирует 600 млн долл. в реализацию этой программы ${ }^{1}$.

В рамках этого подхода в столице достаточно быстро развивается инновационная инфраструктура и IT-технологии, транспортные коммуникации и технопарки. Москва в современном мире - это глобальный город [Sassen 2001: 44]. В 2017 г. Москва впервые попала в топ-7 интеллектуальных мегаполисов мира, войдя в число финалистов премии исследовательской организации Intelligent Community Forum $(I C F)^{2}$. Среди лидеров - австралийские Мельбурн и Ипсуич, канадские Эдмонтон и графство Грей, тайваньские Цзяи и Таоюань. Жюри сравнивало соискателей награды по нескольким критериям: эффективность инфраструктуры, поощрение стартапов, сложность получения высшего образования, работа городских порталов, качество Интернета. Москва оказалась на 2-м месте в мире по числу бесплатных публичных точек доступа к сети $\mathrm{Wi}$ - Fi, в т.ч. в метро; также специалисты обратили внимание на присутствие в московском регионе 26 технопарков и технополисов, которые поддерживают более 1300 высокотехнологичных компаний ${ }^{3}$.

Консалтинговая компания PricewaterhouseCoopers $(P w C)$ провела исследование городов 7 ведущих стран с развивающейся экономикой «От Москвы до СанПаулу» ${ }^{4}$, где Москва заняла 1-е место. Российская столица лидирует по таким направлениям, как инновации, уровень технологической готовности, транспорт и инфраструктура, устойчивое развитие и окружающая среда, демография и приспособленность для жизни. Однако было отмечено, что Москва - один из самых дорогих городов мира по стоимости проживания. В 2017 г. Москва заняла 43-е место в глобальном рейтинге инновационных городов международного рейтингового агентства 2thinknow, поднявшись с 192-го места, которое она занимала в 2011 г.

Сегодня инновационная инфраструктура Москвы включает около 1,5 тыс. объектов, на которых размещены больше 3,5 тыс. ед. современного высокотехнологичного оборудования, в т.ч. 5 :

- особая экономическая зона «Технополис "Москва"»;

- 31 технопарк;

- «Цифровое деловое пространство» - обновленный Центральный дом предпринимателя;

- 76 коворкингов, в каждом из которых оборудованы в среднем по 100 рабочих мест;

-5 центров развития производственных технологий, которые поддерживают малые и средние технологические компании: любой предприниматель может детально отработать технологический процесс, изучить свойства образцов

\footnotetext{
1 Кузнецов Н. Москва превращается в умный город и в центр финансовых технологий. Доступ: http://inosmi.ru/social/20171117/240786809.html (проверено 19.01.2019).

2 The Top7 Intelligent Communities of the Year. URL: http://www.intelligentcommunity.org/top7 (accessed 19.01.2019).

3 Кузнецов Н. Москва превращается в умный город и в центр финансовых технологий. Доступ: http://inosmi.ru/social/20171117/240786809.html (проверено 19.01.2019).

4 Исследование городов семи ведущих стран с развивающейся экономикой «От Москвы до СанПаулу». Доступ: https://www.pwc.ru/ru/government-and-public-sector/assets/e7_2016_rus.pdf (проверено 19.01.2019).

5 Москва - умный город. Доступ: http://www.tadviser.ru/index.php (проверено 19.01.2019).
} 
выпускаемых изделий, сертифицировать новые продукты. В 2017 г. услугами таких центров воспользовались 354 высокотехнологичные компании;

- 2 два инновационных территориальных кластера в Зеленограде и Троицке. Первый специализируется на микроэлектронике и приборостроении (190 участников, свыше 8 тыс. сотрудников), второй - на новых материалах, лазерных и радиационных технологиях (58 участников, около 6 тыс. сотрудников).

Между тем, развитие стартапов в столице требует более серьезного внимания: необходимо развивать инкубаторы идей и хакатоны, как во всех передовых мировых мегаполисах. Пока бизнес-инкубаторы открыты только в ведущих вузах: МГУ, ВШЭ, РЭУ им. Плеханова, МГИМО. Бизнес-инкубатор МГУ по праву лидирует среди московских вузов - он является инкубатором № 1 в России по капитализации резидентов и выпускников, а также входит в пятерку лучших российских инкубаторов по версии Hopes\&Fears. Многие выпускники бизнес-инкубатора МГУ входят в топ-50 российских стартапов 1 .

В перспективе, используя передовой мировой опыт, важно объединить все научные институты города - университеты, лаборатории, научно-производственные комплексы и правительство Москвы для совместной разработки креативных инновационных решений развития города [Котлер и др. 2011: 289290]. Необходимо построить хорошую столичную экосистему стартапов, которая воплотит в себе благоприятную предпринимательскую культуру, где будут активно поощряться эксперименты. Эту задачу можно решить с помощью профессиональных акселераторов, основная задача которых - ускоренное доведение инновационных проектов ранних стадий до первого инвестора.

Хочется подчеркнуть: Москва станет по-настоящему «умным городом», когда граждане, а не технологии будут находиться в центре столичной концепции «умного города». Но пока в этом направлении делаются только первые шаги, направленные на диалог администрации города с гражданами.

С помощью платформы «Активный гражданин» 2 москвичи могут высказывать свое мнение по вопросам развития маршрутов общественного транспорта, развития зеленых зон и парков, различным инфраструктурным проектам. В 2018 г. число пользователей этой платформы превышало 2 млн чел., были реализованы более 1500 предложений.

Платформа «Наш город» 3 представляет собой геоинформационный портал, позволяющий сообщить о конкретной городской проблеме органам власти. Платформа имеет более 1 млн пользователей. Горожане могут получить ответ на свой запрос в течение недели, что позволяет жителям достаточно оперативно решать бытовые проблемы.

Платформа Crowd 4 создана для сбора предложений жителей города по благоустройству столицы (краудсорсинг). 130 тыс. граждан являются пользователями этой платформы, они предложили 84 тыс. идей, из них 2700 включены в список для дальнейшего обсуждения. Однако в 2018 г. были реализованы всего 17 проектов. Таким образом, пока и москвичи не очень активны в поиске креативных предложений по благоустройству столицы, и городские власти не торопятся их претворять в жизнь. Но «умный город» - это, прежде всего, креативный город, который его жители хотят и могут совершенствовать. Поэтому популяризация и развитие платформы Crowd - важное направление в совершенствовании столичных практик «умного города». Название платформы представляется не

\footnotetext{
1 Бизнес-инкубатор МГУ. Доступ: http://www.inmsu.ru/ru/ (проверено 19.01.2019).

2 https://ag.mos.ru/ (проверено 25.01.2019).

3 http://gorod.mos.ru/ (проверено 19.01.2019).

4 Краудсорсинговые проекты Москвы. Доступ: https://www.mos.ru/city/projects/croud/ (проверено 19.01.2019).
} 
совсем удачным: далеко не каждый знает, что такое краудсорсинг. Необходимо дать более яркое и понятное название этой важной платформе: «Город новых идей», «Творческий город» и более активно премировать граждан за самые интересные идеи, писать об этом в прессе, чтобы творческое начинание стало более популярным среди москвичей.

Компания $P w C$ в рамках исследования городов семи ведущих стран с развивающейся экономикой «От Москвы до Сан-Паулу» ${ }^{1}$ провела социологический опрос и выявила, что больше всего отличает Москву от других городов России в лучшую сторону (см. рис. 1).

Как видно из результатов социологического исследования, больше всего столица привлекает возможностями профессионального роста, развитой инфраструктурой развлечений, хорошим качеством IT-сервисов и высоким качеством культурно-эстетической городской среды. Меньше всего привлекает жителей столичный транспорт, высокие расходы на ЖКХ, уровень развития социальных служб.

До сих пор понятие «умный город» в столице означало прежде всего использование информационно-телекоммуникационных технологий (IT-технологий) в городской среде с целью эффективного решения общественных проблем. Но в современной политической науке такое понимание «умного города» характерно для технократического подхода к городскому развитию: оно соответствует концепции «умного города 2.0» [«Умный город»... 2018: 30-33]. Сегодня мировая практика доказывает: узкий технократический подход не способствует развитию человеческого капитала и притоку креативных идей в городское раз-

1 Исследование городов семи ведущих стран с развивающейся экономикой «От Москвы до СанПаулу». Доступ: https://www.pwc.ru/ru/government-and-public-sector/assets/e7_2016_rus.pdf (проверено 19.01.2019).

Что, по вашему мнению, отличает город Москву от других городов России в лучиую сторону? (выберите не более трех вариантов ответа)

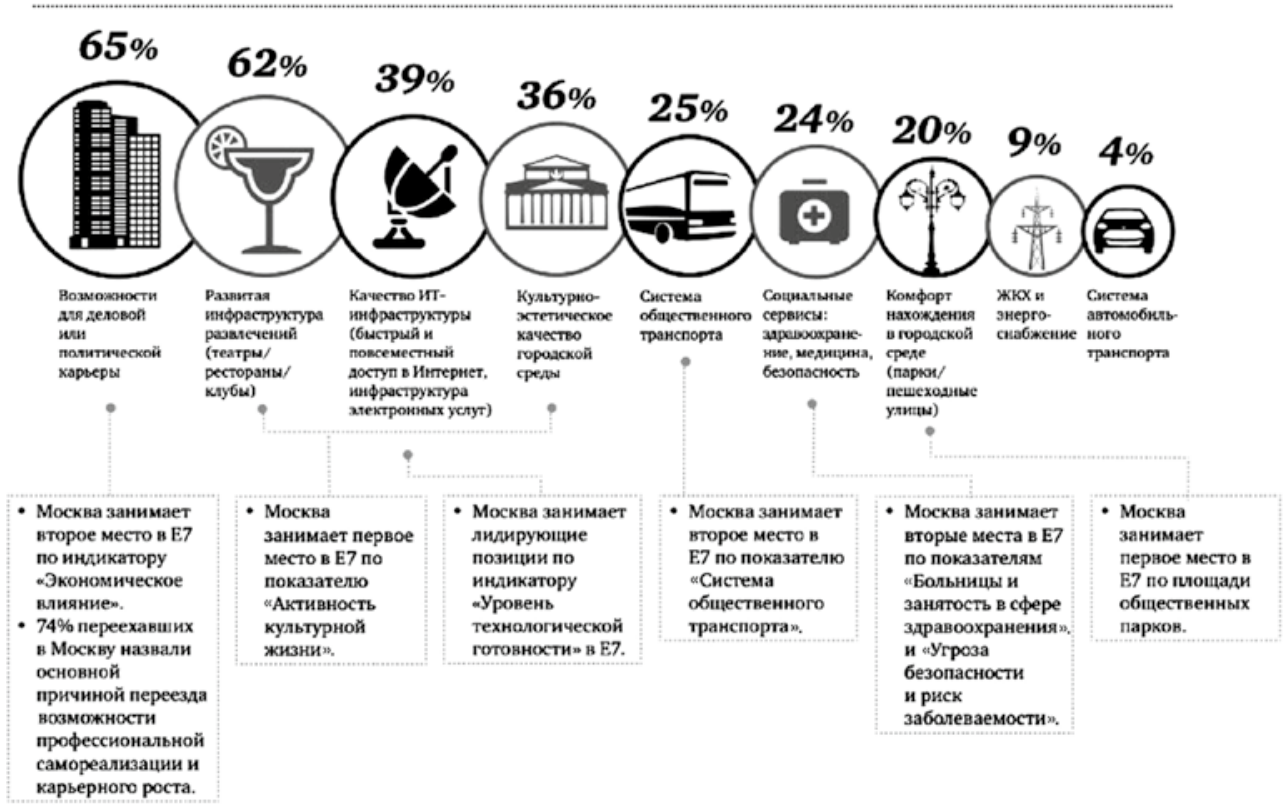

Рисунок 1. Главные позитивные отличия Москвы среди других городов России 
витие. В современной концепции «умного города» понятие «умный» означает не степень развития технологий, а то, насколько общество способно использовать технологии для решения своих проблем и ответов на вызовы времени. Москва как мощный интеллектуальный центр России может стать настоящим креативным городом, где решение всех городских проблем происходит в процессе творческого диалога горожан и городских властей с целью достижения общего блага [Лэндри 2011: 39].

Сегодня уже недостаточно выстроить комфортную городскую среду: необходимо придать ей человекоцентричный вектор. В фокусе внимания властей должны находиться люди, комфорт их проживания и возможности их творческого роста вместе с развитием всего города. Москва имеет все возможности, чтобы уже в ближайшее время перейти от концепции «умного города 2.0» К концепции «умного города 3.0», предполагающей антропоцентричный вектор развития города. Движению столицы вперед очень мешает отсутствие концептуального подхода - разработанной и утвержденной «дорожной карты» строительства интеллектуального мегаполиса. Хочется надеяться, что это произойдет в ближайшем будущем. Сегодня успех любого проекта городского развития во многом определяется тем, насколько хорошо жители осведомлены о его цели и стратегии; насколько они понимают, как стимулируется гражданская активность и реализуются гражданские инициативы. Все это дает людям возможность творчески участвовать в формировании города. И потому проект не остается на бумаге, а обретает реальную жизнь.

\section{Список литературы}

Котлер Ф., Асплунд К., Рейн И., Хайдер Д. 2011. Маркетинг мест. М.: Фонд «Институт экономики города». 384 с.

Лэндри Ч. 2011. Креативный город. М.: ИД «Классика-ХХІ». 232 с.

«Умный город» ХХІ века: возможности и риски смарт-технологий в городском ребрендинге (под ред. И.А. Василенко). 2018. М.: Международные отношения. $256 \mathrm{c}$.

Sassen S. 2001. The Global City: London, New York, Tokyo. $2^{\text {nd }}$ ed. Princeton: Princeton University Press. 240 p.

\section{MOSCOW AS A SMART CITY: MAIN DIRECTIONS AND PROSPECTS OF SMART STRATEGIES OF THE CAPITAL DEVELOPMENT}

\footnotetext{
Abstract. The article deals with the problems of creating the image of Moscow as a Smart City, based on smart management, intelligent human environment, and smart technologies of city communications. The author believes that the capital should move away from the technocratic approach to the formation of a Smart City in favor of an anthropocentric one, turned to a person, and not to technology and proposes developing a road map for the development of a Smart City in the capital as a humanistic project for the benefit of all-round human development.

Keywords: Moscow image, Smart City, smart technologies
} 